\title{
Mutants of Tobacco mosaic virus with Temperature-Sensitive Coat Proteins Induce Heat Shock Response in Tobacco Leaves
}

\author{
Harald Jockusch, Christiane Wiegand, Birgit Mersch, and Daniela Rajes \\ Developmental Biology and Molecular Pathology, University of Bielefeld, D-33501 Bielefeld, Germany \\ Submitted 25 October 2000; Accepted 19 March 2001.
}

We analyzed, with respect to heat shock proteins (HSPs), systemically reacting tobacco leaves inoculated with $\mathrm{To}$ bacco mosaic virus (TMV), wild-type vulgare, and temperature-sensitive coat protein (CP) mutants $\mathrm{Ni} 118$ (P20L) and flavum (D19A), kept at 23 or $30^{\circ} \mathrm{C}$. HSP18 and HSP70 $\mathrm{mRNAs}$ and proteins were induced with temperature-sensitive $\mathrm{CP}$ mutants after 1 to 2 days at $30^{\circ} \mathrm{C}$. After 4 to 6 days, HSP70 was also induced at $23^{\circ} \mathrm{C}$. The induction of HSPs paralleled the amount of insoluble TMV CP in leaf extracts, indicating that denatured TMV CP by itself induces a heat-shock response.

As the result of single amino acid replacements, the coat proteins (CPs) of a number of Tobacco mosaic virus (TMV) mutants are extremely temperature labile, i.e., at moderately elevated temperatures, they misfold and form insoluble aggregates rather than virus particles (Jockusch 1964; Jockusch 1966a; Jockusch 1966c; Jockusch 1968b). Yet under such "nonpermissive" conditions, temperaturesensitive CP mutants spread in the plant similarly to the wild-type, temperature-resistant TMV, which indicates that their replication and motility functions are not impaired (Jockusch 1966b; Jockusch 1968a). In model experiments on Xenopus laevis oocytes, microinjected, denatured bovine serum albumin elicited a heat shock response, whereas native albumin did not (Ananthan et al. 1986). We therefore tested whether denatured CPs of temperature-sensitive TMV mutants would elicit a heat shock response (Neumann et al. 1989; Vierling 1991) in infected leaves at moderately elevated temperatures.

We used wild-type TMV temperature-resistant vulgare and two temperature-sensitive CP mutants, $\mathrm{Ni}$ 118, with the amino acid replacement P20L, and flavum (Melchers 1942), with D19A (Wittmann 1962; Wittmann 1964; Wittmann and Wittmann-Liebold 1966), as confirmed by sequencing the reverse transcription-polymerase chain reaction (RT-PCR) products of CP genes. Within positions 5,600 to 6,190 (Goelet et al. 1982), no additional base changes were found, indicating a rather low level of as yet undetected mutations (cf. Zimmern and Hunter 1983).

Corresponding author: H. Jockusch; Fax: +49 521106 5654; E-mail: h.jockusch@biologie.uni-bielefeld.de
Mature leaves of systemically reacting tobacco plants (Nicotiana tabacum cv. Samsun n/n) were dusted with carborundum and inoculated with $0.5 \mathrm{mg}$ of purified TMV per $\mathrm{ml}$. After 1 day at $23^{\circ} \mathrm{C}$, half of the plants were shifted to $30^{\circ} \mathrm{C}$. At 1 to 6 days later, leaves were harvested and shock frozen in liquid N2.

To analyze for proteins, $500 \mathrm{mg}$ of frozen leaves were homogenized in $1,000 \mu \mathrm{l}$ of $100 \mathrm{mM} \mathrm{Na}$ phosphate, $5 \mathrm{mM}$ ascorbate, $10 \mathrm{mM}$ EDTA, and $5 \mathrm{mM}$ dithioerythrol. The homogenate was centrifuged at $10,000 \mathrm{~g}$ for $30 \mathrm{~min}$ to $80 \mu \mathrm{l}$ of supernatant $20 \mu \mathrm{l}$ of sodium dodecyl sulfate (SDS) containing dissociation buffer were added. The sediment was washed twice with 1,000 $\mu \mathrm{l}$ of extraction buffer and taken up in SDS dissociation buffer in order to adjust the concentration (in reference to fresh weight) to that of the supernatant. Proteins were separated on SDS polyacrylamide gels, which were fixed and stained with Coomassie brilliant blue or blotted onto Protran nitrocellulose filters (Schleicher and Schuell, Dassel, Germany). TMV CP was identified by a monoclonal antibody against intact vulgare virus, which also reacted with SDS denatured TMV CP.

At $23^{\circ} \mathrm{C}$, soluble TMV CP comprising native $\mathrm{CP}$ and virions was in the supernatant of the nondenatured extracts. Under nonpermissive conditions, e.g., with temperature-sensitive mutants at elevated temperatures, most of the $\mathrm{CP}$ was in the pellet as a result of denaturation and aggregation (Jockusch 1966a; Jockusch 1968a; Jockusch 1968b). At $30^{\circ} \mathrm{C}$, however, some wild-type $\mathrm{CP}$ denatures, whereas a sizable proportion of the $\mathrm{CP}$ of temperature-sensitive mutants already denature at $23^{\circ} \mathrm{C}$ (Fig. 1).

To detect HSP18 (Mansfield and Key 1987), we used a polyclonal anti-Arabidopsis HSP18 that reacted only with nondenatured HSP18 of tobacco on dot blots. There was a positive reaction with anti-HSP18 1 day after temperature shift in all samples, including mock inoculation. One day later, there were stronger responses, as indicated by antibody staining at higher dilutions, with $\mathrm{Ni} 118$ and flavum at $30^{\circ} \mathrm{C}$ (Fig. 2A).

A monoclonal antibody against bovine brain uncoating ATPase (Höning et al. 1994) was used to detect HSP70 (Aranda et al. 1996) on immunoblots after SDS electrophoresis (Fig. 2B). Initially, HSP70 was detected after inoculation, even in mock-inoculated leaves. On day 2, signals from $\mathrm{Ni} 118$ and flavum-inoculated leaves were by far the highest, exceeding the $48^{\circ} \mathrm{C}$ positive control. At approximately day 4 , the tem- 
perature-sensitive mutants gave signals, even at $23^{\circ} \mathrm{C}$, and on day 6 , the signals were still specific for the temperaturesensitive mutants, although not different for 23 and $30^{\circ} \mathrm{C}$. Additionally, there were no signals above background upon incubation at $30^{\circ} \mathrm{C}$ alone.

Total RNA was extracted from frozen leaves with the plant RNA version of the RNase Kit (Qiagen, Hilden, Germany). Four days after the shift, there were intense 6-kb TMV RNA bands in vulgare-infected plants, at 23 and $30^{\circ} \mathrm{C}$, in ethidium bromide-stained RNA gels. With $\mathrm{Ni} 118$ and flavum, bands were weaker and seen only at the lower, permissive temperature (not shown). Most likely, these bands reflect TMV RNA packaged in virions, a function defective with temperaturesensitive mutants at $30^{\circ} \mathrm{C}$ and already impaired at the permissive temperature. The primers used to sequence the $\mathrm{CP}$ gene and detect the CP message of TMV were based on Goelet et al. (1982). TMV-CPs: GTAGTAATGATCGGTCAGTGC; TMV-CPas1: CGCTCCTTATGGCCACCG; TMV-CPas2: TATTATGCATCTTGACTACC; for HSP18, HSP18s: GGAGCAATATTTTCGACCCG; HSP18as: CCCAAAATATCCAACACATCC (accession no X70688); for HSP70, HSP70s: GGTGAAGAGAAACAGTTTGCTC; HSP70as: CTCCTCAGAGCTCTAGCATTG (accession no. X63106); for actin, AtactS: GAGAAGATGACTCAGATC; and Atact-A: ATCCTTCCTGATATCGAC (accession no. U37281).
Leaf RNAs were analyzed by RT-PCR. One day after temperature adjustments, the 507-bp amplificate of CP sequence (representing the $\mathrm{CP}$ message) was present in high amounts with vulgare and the temperature-sensitive mutants at both temperatures (Fig. 3A). All samples, except the uninfected control at $23^{\circ} \mathrm{C}$, showed HSP18 amplificate. Next intense to the positive-control, uninfected leaves heat shocked at $48^{\circ} \mathrm{C}$, were the bands of temperature-sensitive, mutantinfected leaves at $30^{\circ} \mathrm{C}$, followed by those at $23^{\circ} \mathrm{C}$ and the vulgare-infected samples (Fig. 3B). Thus, the levels of HSP18 mRNA amplificate 1 day after temperature shift were roughly equivalent to the corresponding protein levels 2 days after the shift.

With HSP70 RT-PCR, signal intensities were $\mathrm{F} 30^{\circ} \mathrm{C} \sim \mathrm{Ni}$ $118,30^{\circ} \mathrm{C}>\mathrm{F} 23^{\circ} \mathrm{C}>N i 118,23^{\circ} \mathrm{C} \sim$ vulgare, $30^{\circ} \mathrm{C}>$ vulgare; $23^{\circ} \mathrm{C}$ (Fig. 3C). Whereas with HSP18 there was a "background" response to the $30^{\circ} \mathrm{C}$ incubation alone, the HSP70 reaction was highly specific to TMV infection.

The difference between temperature-resistant and temperature-sensitive CPs is not all or nothing but is reflective of shifts in the "melting temperatures" of tertiary structures (Jockusch 1968b). Even the CP of vulgare, with a melting temperature of $36^{\circ} \mathrm{C}$, is relatively labile, and some denatured $\mathrm{CP}$ is produced by TMV vulgare at $30^{\circ} \mathrm{C}$. Moreover, with $\mathrm{Ni}$ $118 \mathrm{CP}$, with a melting temperature of $27^{\circ} \mathrm{C}$, denatured $\mathrm{CP}$ and

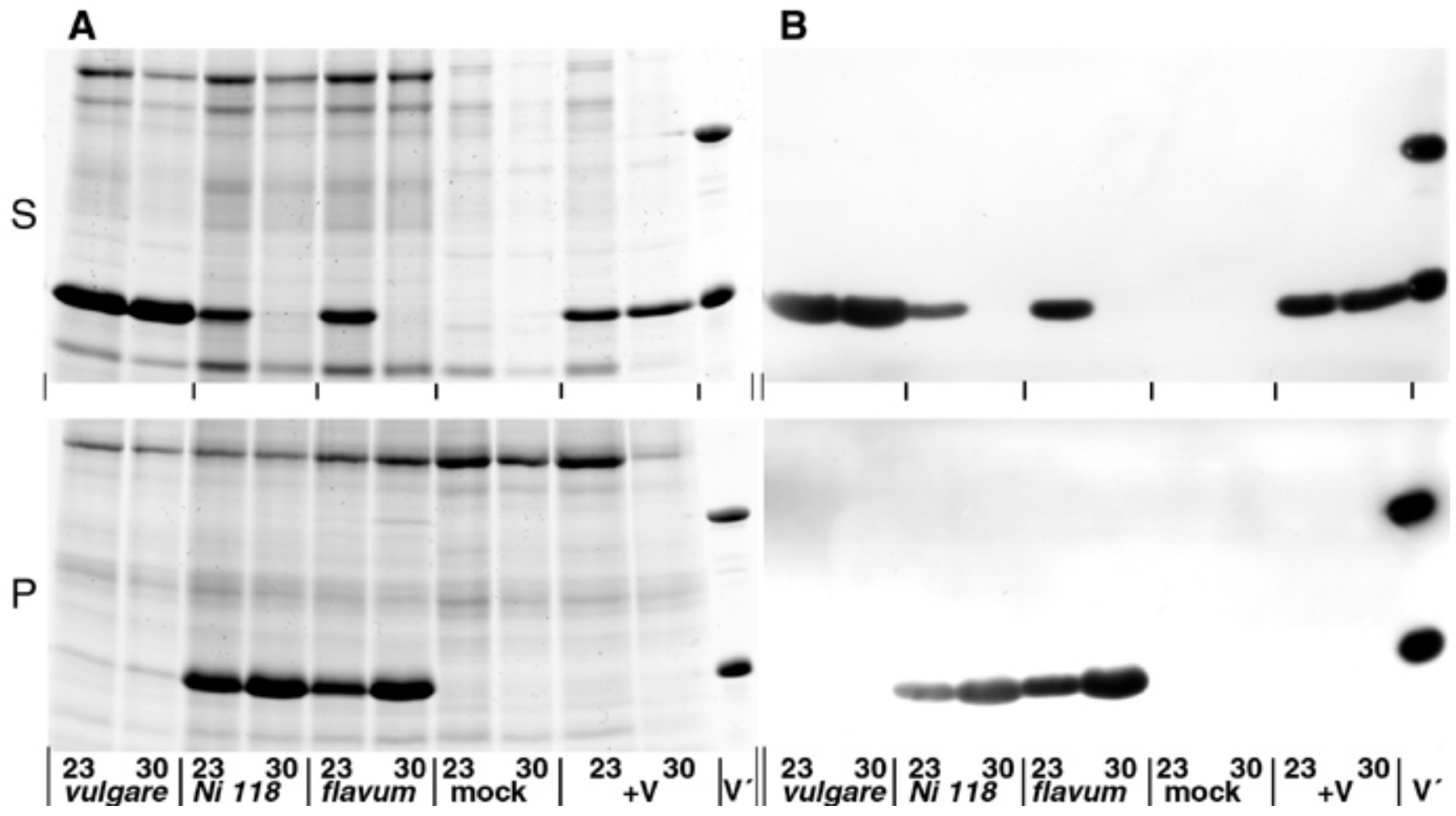

Fig. 1. Native and denatured Tobacco mosaic virus (TMV) coat proteins (CPs) in leaf tissue inoculated with the wild-strain vulgare temperature-resistant and temperature-sensitive mutants, $\mathrm{Ni} 118$ and flavum, respectively, kept at $23^{\circ} \mathrm{C}(23)$ or shifted to $30^{\circ} \mathrm{C}(30)$ and harvested 6 days after the shift. Supernatants (S) and washed pellets $(\mathrm{P})$ of extracts corresponding to $3 \mathrm{mg}$ of fresh weight per lane were subjected to sodium dodecyl sulfate-polyacrylamide gel electrophoresis (12.5\% polyacrylamide, $90 \mathrm{~min} \times 10 \mathrm{~V}$ per cm) and A, stained with Coomassie blue or B, immunoblotted with anti-TMV or X-ray film exposed to ECL-developed filter. Mock: Leaves rubbed with phosphate buffer without TMV. +V: $1 \mathrm{mg}$ of TMV added to $500 \mathrm{mg}$ of mockinoculated leaf material prior to homogenization; $\mathrm{V}^{\prime}: 1 \mu \mathrm{g}$ of oxidized virus preparation. Lower band: $\mathrm{CP}$ monomer, $17.5 \mathrm{KDa}$. Upper band: CP dimer, $35 \mathrm{KDa}$. When measured by dye elution, TMV-infected leaves contained $6-8 \mathrm{mg}$ of TMV CP per g of tissue. Fractions soluble-total CP: V $23^{\circ},<0.01$; V $30^{\circ}, \leq 0.02 ; 11823^{\circ}, 0.67 ; 11830^{\circ},>0.95 ; \mathrm{F} 23^{\circ}, 0.55 ; \mathrm{F} 30^{\circ},>0.95$. 

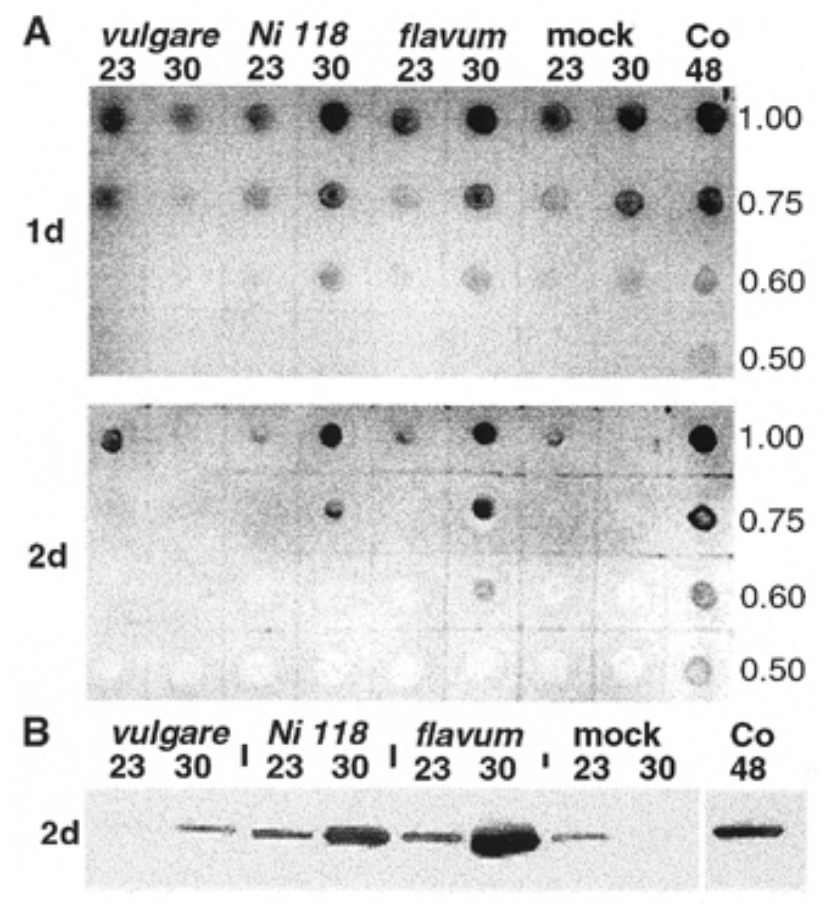

4d

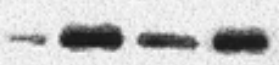

$6 d$

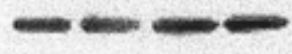

Fig. 2. Levels of HSP18 and HSP70 as shown by antibody detection in soluble leaf extracts (second antibody is horseradish peroxidase [HRP] conjugated). Positive-control (48) leaf tissue heat shocked for $2 \mathrm{~h}$ at $48^{\circ} \mathrm{C}$. A, Dot blot stained with polyclonal anti-HSP18. Incubation period of plants after shift to experimental temperature (left) and relative concentrations of extracts (right). HRP-chloronaphtol development. B, Immunoblot after sodium dodecyl sulfate electrophoresis (10\% polyacrylamide, approximately $3 \mathrm{mg}$ of fresh weight per lane) stained with monoclonal anti-HSP70. Co 48: Positive control as in A. X-ray film exposed to HRP-ECL-developed filter.

reduced virus yields are also found at $23^{\circ} \mathrm{C}$. Denatured TMV CPs accumulate in the insoluble fraction but also may be degraded preferentially by proteolysis. The low level of unspecific mutations in Ni 118 and flavum support the view that the temperature-sensitive CP mutations are indeed responsible for the heat-shock responses described. Thus, the notion that denatured proteins can induce a heat-shock response, as shown in an animal cell model (Ananthan et al. 1986), seems to also hold for the tobacco-TMV system.

\section{ACKNOWLEDGMENTS}

Dedicated to the memories of two outstanding academic teachers of H. Jockusch: G. Melchers (1906-1997) and H.-G. Wittmann (19271990). We thank K.-W. Mundry (University of Stuttgart) for samples of TMV mutants, F. Schöffl (University of Tübingen) for anti-HSP18 and discussions, B. M. Jockusch and Sabine Buchmeier (TU Braunschweig) for anti-HSP70 and help with anti-TMV, L. Schilde (University of Tübingen) for tobacco strains, and L. Nover (University of Frankfurt) for discussions.
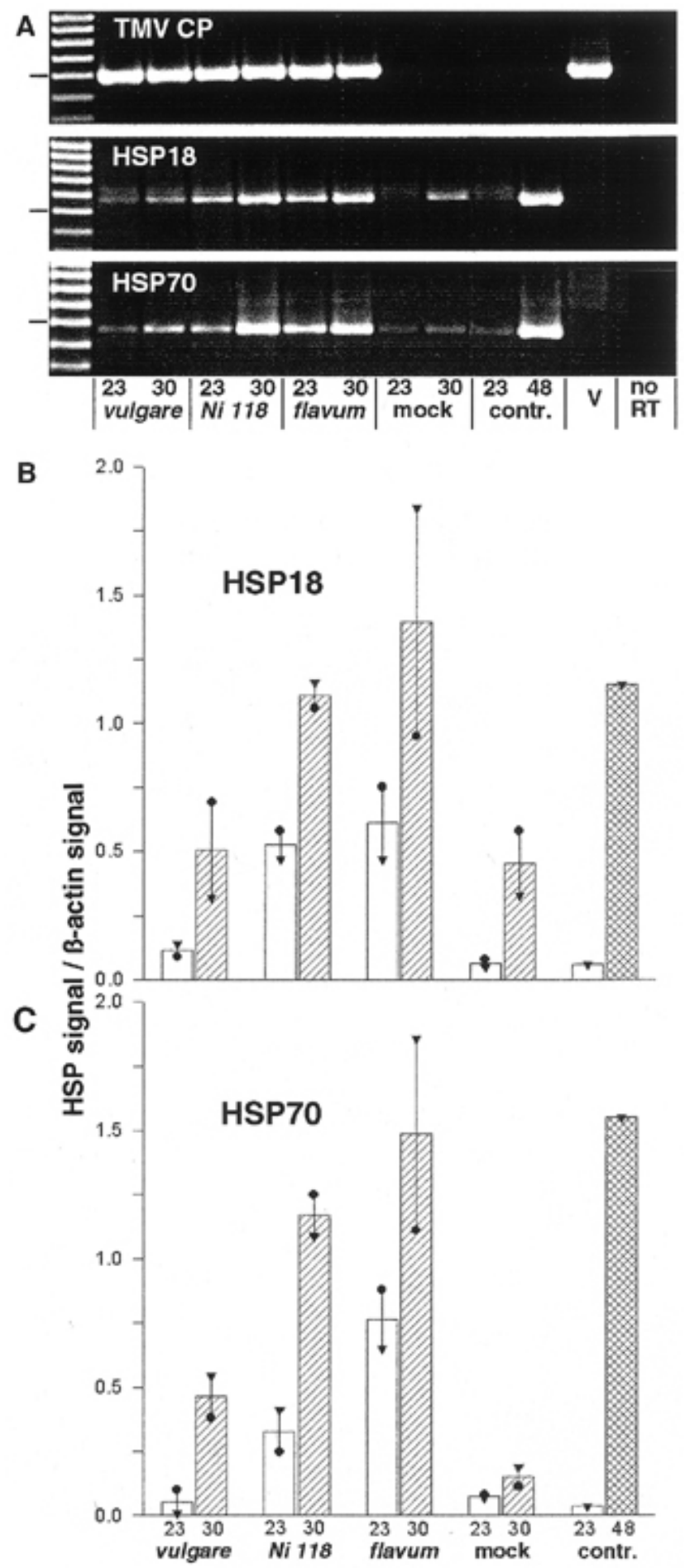

Fig. 3. Tobacco mosaic virus (TMV) coat protein, HSP18, and HSP70 mRNA levels as estimated by reverse transcription-polymerase chain reaction. A, Gels after ethidium bromide (EtBr) staining, UV images. Bars to the left: $500 \mathrm{bp}$. $\mathbf{B}$ and $\mathbf{C}, \mathrm{EtBr}$ signals relative to the $\beta$-actin signal. Combined results from two independent experiments, with individual results indicated by $\bullet$ and $\mathbf{\Delta}$. Contr. 23: Untreated tobacco leaves grown at $23^{\circ} \mathrm{C}$. Contr. 48 : Leaf tissue heat shocked for $2 \mathrm{~h}$ at $48^{\circ} \mathrm{C} \mathbf{B}$, HSP18 mRNA; C, HSP70 mRNA. 


\section{LITERATURE CITED}

Ananthan, J., Goldberg, A. L., and Voellmy, R. 1986. Abnormal proteins serve as eukaryotic stress signals and trigger the activation of heat shock genes. Science 232:252-254.

Aranda, M. A., Escaler, M., Wang, D., and Maule, A. J. 1996. Induction of HSP70 and polyubiquitin expression associated with plant virus replication. Proc. Natl. Acad. Sci. USA 93:15289-15293.

Goelet, P., Lomonossoff, G. P., Butler, P. J. G., Akam, M. E., Gait, M. J., and Karn, J. 1982. Nucleotide sequence of tobacco mosaic virus RNA. Proc. Natl. Acad. Sci. USA 79:5818-5822.

Höning, S., Kreimer, G., Robenek, H., and Jockusch, B. M. 1994. Receptor-mediated endocytosis is sensitive to antibodies against the uncoating ATPase (hsc70). J. Cell Sci. 107:1185-1196.

Jockusch, H. 1964. In vivo- und in vitro-Verhalten temperatursensitiver Mutanten des Tabakmosaikvirus. Z. Vererbungsl. 95:379-382.

Jockusch, H. 1966a. Relations between temperature sensitivity, amino acid replacements, and quaternary structure of mutant proteins. Biochem. Biophys. Res. Comm. 24:577-583.

Jockusch, H. 1966b. Temperatursensitive Mutanten des Tabakmosaikvirus. I. In vivo-Verhalten. Z. Vererbungsl. 98:320-343.

Jockusch, H. 1966c. Temperatursensitive Mutanten des Tabakmosaikvirus. II. In vitro-Verhalten. Z. Vererbungsl. 98:344-362.

Jockusch, H. 1968a. Two mutants of tobacco mosaic virus temperature- sensitive in two different functions. Virology 35:94-101.

Jockusch, H. 1968b. Stability and genetic variation of a structural protein. Naturwissenschaften 11:514-518.

Mansfield, M. A., and Key, J. L. 1987. Synthesis of the low molecular weight heat shock proteins in plants. Plant Physiol. 84:1007-1017.

Melchers, G. 1942. Über einige Mutationen des Tabakmosaikvirus und eine "Parallelmutation" des Tomatenmosaikvirus. Naturwissenschaften 30:48.

Neumann, D., Nover, L., Parthier, B., Rieger, R., Scharf, K.-D. 1989. Heat shock and other stress response systems of plants. Biol. Zentbl. 108:1-156.

Vierling, E. 1991. The roles of heat shock proteins in plants. Ann. Rev. Plant Physiol. Plant Mol. Biol. 42:579-620.

Wittmann, H. G. 1962. Proteinuntersuchungen an Mutanten des Tabakmosaikvirus als Beitrag zum Problem des genetischen Codes. Z. Vererbungsl. 93:491-530.

Wittmann, H. G. 1964. Proteinanalysen von chemisch induzierten Mutanten des Tabakmosaikvirus. Z. Vererbungsl. 95:333-344.

Wittmann, H. G., and Wittmann-Liebold, B. 1966. Protein chemical studies on two RNA viruses and their mutants. Cold Spring Harbor Symp. Quant. Biol. 31:163-172.

Zimmern, D., and Hunter, T. 1983. Point mutation in the $30-\mathrm{K}$ open reading frame of TMV implicated in temperature-sensitive assembly and local lesion spreading of mutant Ni 2519. EMBO J. 2:1893-1900. 